\title{
TSILHQOT'IN NATION V. BRITISH COLUMBIA AND CIVIL JUSTICE: ANALYZING THE ProceduRAL INTERACTION OF EVIDENTIARY Principles and Aboriginal Oral History
}

\author{
DWIGHT G. NEWMAN"
}

\section{INTRODUCTION}

The Supreme Court of Canada's decision in Delgamuukw' has been widely lauded by legal scholars both for taking major steps forward in the definition of Aboriginal rights and for overcoming an unjust evidentiary barrier to the appropriate hearing of Aboriginal claims (although not without suggestions that the Court could have gone further). ${ }^{2}$ Yet, that judgment's ruling that oral history was broadly admissible as evidence in Aboriginal claims, ${ }^{3}$ despite the Court's encounter with the issues of and later comments on the application of evidentiary principles to oral history in Mitchell, ${ }^{4}$ has not been subjected to the sort of careful analysis necessary to operationalize it in a fully predictable and practical manner. For instance, questions remain on what precisely it implies for the application of the principles

Tutor in Jurisprudence and Public International Law and D.Phil. candidate, Oxford University: from I July 2005, Assistant Professor of Law, University of Saskatchewan College of Law. I thank Simonne Horwitz for our discussions on oral history.

Delgamumhr v. British Columbia. [1997] 3 S.C.R. 1010 [De/gamumkw]

An American Society of International Law Panel treated De/gamumhur as a "landmark case" for its advancement of the use of oral history evidence: "The Creation Story of Peoples" (1999) $93 \mathrm{Am}$. Soc' $\mathrm{y}$ Int'I L. Proc. \$2 at 53. For some of the Canadian commentary on the case, see e.g. Paul R. Cassidy. "S.C.C.'s Delgamuukw Ruling Will Revolutionize the Law" (1998) 17 Lawyers Weekly' 9(2); David W. Elliott. "Deigamuukw: Back to Court?" (1998) 26 Man. L.J. 97: Jonathan Rudin, "One Step Forward, Two Steps Back: The Political and Institutional Dynamics Behind the Supreme Court of Canada's Decisions in R. v. Sparrou', $R$. v. Van der Peet and Delgamuuku' v. British Columbia" (1998) 13 J. L. \& Social Pol'y 67; John Borrows, "Sovereignty's Alchemy: An Analysis of Delgamuukw v. British Columbia" (1999) 37 Osgoode Hall L.J. 537; Kerry Wilkins, "Take Your Time and Do It Right: Delgamuukw. Self-Government Rights and the Pragmatics of Advocacy" (2000) 27 Man. L.J. 24I: Gordon Christic, "Delgameukw and the Protection of Aboriginal Land Interests" (2000-2001) 32 Ottawa L. Rev. 85: Brent Olthuis, "Defrosting Delgammukw for '/low to Reject a Frozen Rights Interpretation of Aboriginal Title in Canada')" (2000-2001) 12 N.J.C.L. 385. Comments more specifically on the aspects related to evidence law include: Sandra $A$. Forbes. "Developments in the Law of Evidence: The 1997-98 Term" (1999) 10 Sup. Ct. L. Rev. 385; Kent MeNeil. "The Onus of Proof of Aboriginal Tille" (1999) 37 Osgoode Hall L..J. 775: André Bourcier, "Aspects linguistiques de la preuve par tradition orale en droit autochtone" (2000) 4 I C. de D. 403; Andie Diane Palmer. "Evidence 'not in a form familiar to common law courts': Assessing Oral l listories in Land Claims Testimony After Delgamunkw v. B.C." (2001) 38 Alta. L. Rev. 1040. The evidentiary issues had also been presciently addressed after the trial judgment: Geofr Sherrot,, "The Court's Treatment of the Evidence in Delgamukhw v. B.C." (1992) 56 Sask. L. Rev. 441; Clay Mcl.cod. "The Oral Histories of Canada's Northern Pcople. Anglo-Canadian Evidence Law, and Canada's liduciary Duty to First Nations: Breaking Down the Barriers of the Past" (1992) 30 Alta. L. Rev. 1276: Michalel Ascli \& Catherine Bell. "Definition and Inkerpretation of Fact in Canadian Aboriginal Tille Litigation: An Analysis of Delgammekw" (1993.94) 19 Queen's L.J. 503. Materials in some Continuing Legal Education programs have also seen Delgamushw' as oflering new hopes on evidentiary issues, though not without atlention to some of the praclical challenges: e.g. in B.C.'s CL.F materials. Stuart Rush. "Use of Oral History Evidence in Aboriginal Rights Legislation," online: < uww cle be ca/Cle/Practice+Desk/Practice +Articles/Collection/02-app-oralhistory evidence>.

Delgamuskw, supra note I at para. 87.

Mitchell v. M.N.R., [2001] 1 S.C.R. 911, 2001 SCC 33 [Mirchell]. 
of evidence law, such as those goveming hearsay, in the Aboriginal claims context. ${ }^{5}$ How is the use of oral history as part of the aspiration toward justice for Aboriginal peoples reconciled with the practical needs of a civil justice system? How do judges operationalize this law through the common law development of appropriate civil procedure in relation to the admission of such evidence?

This lacuna in legal analysis has, however, now been tackled in the very sort of context in which it poses the greatest challenges and the sort least likely to attract the external attention it deserves - in a February 2004 preliminary trial court order of the British Columbia Supreme Court in Tsilhgot'in Nation v. British Columbia. ${ }^{6}$ Despite the fact that there were an estimated two years to go on this trial, ${ }^{7}$ and despite Vickers J.'s protestations that he envisioned his order as simply a preliminary order for "this case" and "not a formula or template to be applied in every case where hearsay evidence of oral history, genealogy, practices, events, customs and traditions are a critical part of the evidence at trial," singular nature of the Tsilhgor 'in Nation order as a procedural approach to the problem and the issues it confronts make it an appropriate focus of further legal and theoretical analysis. The Tsilhqot 'in Nation order is likely to help shape a standard in the use of oral history in Aboriginal law contexts more broadly, thus giving it a significance far beyond that often attached to a trial court's preliminary order. 'Indeed, it is already drawing the attention of legal departments elsewhere in Canada, ${ }^{10}$ so we can appropriately take the judgment on the Tsilhqot 'in Nation order as an important source helping to frame the debates around how to operationalize Delgamtukw and the resulting principles on oral history.

3. This is ironic given that Delgamumkw, supra note I at para. 3, identified itself as meant to make clearer the truly vague statement of $R$. v. Van der Peet, [1996] 2 S.C.R. 507 at para. 68 [Van der Peet]. Tsilhqot 'in Nation v. British Columbia, [2004] 5 W.W.R. 320, 2004 BCSC 148 [Tsilhgot 'in Nation] (in some contexts, such as the Alberta government's legal update on the case, infra note 10, it has been cited undet the name William v. British Columbia, after the lead plaintiff, Roger William. Chief Roger William acts in the case as a representative of all members of the Xeni Gwet'in First Nations Government and the Tsilhqot in Nation (which encompasses the Xeni Gwet'in and five other communities), so the case has also been cited under the name Xeni Gwet 'in First Nations v. Bristsh Columbia, though I will refer to it throughout as Tsithqot in Nation v. British Columbia). As will be a subject of discussion later below, this order resulted rapidly in a further heasing in May 2004 secking to apply the order to some particular evidence from the case: Tsilhqor 'in Nation v. British Columbia (2004), 33 B.C.L.R. (4th) 359, 2004 BCSC 1022 [Tsithqot' in Nation Application].

7 sillhqot in Nation, supra note 6 at para. 9.

Jbid. at para. 23.

Despite the substantial influence of legal realism and its offshoots in the Canadian legal academy, and these movements' emphasis on the importance of fact-finding, Canadian legal scholars, no doubt responding to the continuing importance of stare decisis, generally continue to focus their attentions and energies on appellate jurisprudence, purified of factual issues. However, evidence law cannot refuse an encounter with factuality. The study of important trial orders is inherently vital to an understanding of the law, and more so here where the order will no doube have ongoing influence as a persuasive authority.

II' See c.g. Alberta's Department of Aboriginal Affairs and Northern Development posted a legal update concerning the case on 4 March 2004. online: <www.aand.gov.ab.ca/PDFs/William\%20e1\%20al.\% 20v.\%20British\%20Columbia\%20e1\%20al.pds. Other legal departments have, of course, also been discussing the case internally, though their discussions remain confidential and cannot be cited here. The case is of particular importance for jurisdictions, like Alberta, that face widespread issues around Aboriginal rights claims and where Aboriginal peoples form a relatively large proportion of the population. 
Part Il of this comment will set out the facts and issues of Tsilhqof 'in Nation, thereby further manifesting the significance of the case. Part III will offer briefly a theoretical framework on the interaction between evidence law and substantive issues, arguing that there are inherently mutual interactions between them whose resolution falls to be determined on a combined consideration of justice and a fair justice syslem (values I will draw partly from their more cross-systemic enunciation). This Part will seek to briefly show how the general principles enunciated in Delgamuukw and Mitchell incorporate those values, thereby entrenching a theoretical reconciliation between evidentiary principles such as those governing hearsay and judicial principles recognizing Aboriginal oral history as appropriate evidence. Part IV will probe Tsilhqo ' in Nation's response to that reconciliation in a more practical context, arguing that its principles are a reasonable effort toward a practical reconciliation, that they thus appropriately have a more general application, but that some additional principles present in recent American legal discussion on Aboriginal oral history issues might usefully enhance the principled practical framework we can appropriately develop in future Canadian legal discourse.

\section{THE TSILHQOT'IN NATION ORDER}

In the Tsilhqo' 'in Nation case, the lead plaintiff Roger William is seeking declarations of Aboriginal rights and title on behalf of the Tsilhqot'in and Xeni Gwet'in First Nations. In the course of doing so, the plaintiff has brought what would ordinarily be hearsay evidence of their oral history and traditions, evidence which was pertinent to the necessary elements of the claims for Aboriginal rights and titles. The order with which we are concerned was issued in response to the defendants' objections to the lack of a formal process around the introduction of this hearsay evidence.

The defendant Canada sought an order that such evidence be introduced only after qualification of individual witnesses as expert witnesses on these First Nations' oral history through a voir dire or preliminary inquiry procedure." The defendant British Columbia sought a more complex order permitting hearsay evidence on genealogy and traditional activities or practices based on a voir dire establishing the necessity or usefulness and reasonable reliability of the introduction of the hearsay evidence, and permitting hearsay evidence on past events with a similar hearing supplemented by expert testimony on the context for the particular Aboriginal group's transmission of oral traditions. ${ }^{12}$ The plaintiff argued against the introduction of such processes and argued that the reliability of the oral evidence could best be determined in the context of all the evidence in the case. ${ }^{13}$ Justice Vickers expressed some sympathy with this latter claim, referring to the evidence the plaintiff planned to introduce from an anthropologist as giving some preliminary indication of reliability of oral history accounts, which the anthropologist indicated members of these First Nations would be very reluctant to report unless convinced of their accuracy, though Vickers J. also explained that his final finding of fact at the conclusion of the trial could still differ. ${ }^{14}$ 
Justice Vickers identified from the existing Supreme Court of Canada case law a discretion in the trial judge, noting a dictum of McLachlin C.J.C. that "inquiries as to the witness's ability to know and testify to orally transmitted aboriginal traditions and history may be appropriate" and emphasizing that the dictum used the word "may" rather than "must." also identified in that body of case law the basic expectation that decisions in Aboriginal claims must be founded on evidence, but that the law of evidence must be applied flexibly, "commensurate with the inherent difficulties posed by such claims and the promise of reconciliation embodied in s. 35(1)."16

As a result, Vickers $\mathrm{J}$. indicated that he would not establish a formal process but that the admission of hearsay fell to be determined on the normal principles applying to the admission of hearsay, with the addition of a need for attentiveness to this "promise of reconciliation embodied in 5. 35(1)." "17 In practical terms, however, Vickers J. did go on to establish an informal process. Though he declined the option of a formal voir dire on the testimony of each witness bringing oral history evidence, ${ }^{18}$ he did indicate a process to enable holding the testimony up to the requirements for admissibility of hearsay evidence on the Khan ${ }^{19}$ test, discussed below, which applies to other hearsay evidence. ${ }^{20}$ Thus, Vickers J. indicated a preference for non-hearsay testimony of an event if persons who had witnessed it were alive and able to appear as witnesses but accepted the necessity of hearsay testimony in other circumstances. ${ }^{21}$ However, he also indicated the need for a searching probe into reliability of hearsay testimony, indicating that the court "would want to know" the following:

(1) some personal information concerning the [ wilness'] circumstances and ability to recount what others have told him or her;

(2) Who it was that told the witness about the event or story:

(3) the relationship of the witness to the person from whom he or she learned of the event or story;

(4) the general reputation of the person from whom the witness learned of the event or story:

(5) whether that person witnessed the event or was simply told of it: and,

(6) any other matters that might bear on the question of whether the evidence tendered can be relied upon by the trier of fact to make critical findings of fact. ${ }^{22}$

Ibid. at para. 10, citing Mitchell. supra note 4 at para. 33 .

Ibid. at para. 12. citing Mirchell, supra note 4 at para. 29 . See also para, 13 of the Tsilhqot 'in Nation. supra note 6 citing paras. 30 and 39 of Afichell.

Tsilhqui 'in Nation, ibid. at para. 16.

lbid. at para. 17.

R. v. Khan, [1990] 2 S.C.R. 531 [Khan].

Ibid.

Tsilhqot in Nation, supra note 6 at para. 18.

Ibid. al para. 19. 
In order to enable such consideration of the reliability of hearsay evidence, going to both admissibility and weight, ${ }^{23}$ Vickers $\mathrm{J}$. established two elements to the process. First, he indicated a helpful practice for the start of the trial:

At the outset of the trial it would be helpful for counsel to outline the traditions of the people they represent relating to the questions of: 1) how their oral history, stories, legends, customs and traditions are preserved: 2) who is entitled to relate such things and whether there is a hierarchy in that regard; 3) the community practice with respect to safeguarding the integrity of its oral histon;. stories, legends and (taditions; 4) who will be called at trial to relate such evidence. and the reasons they are being called to testify. ${ }^{24}$

Then, there would also be a preliminary inquiry (not in the form of a voir dire but at the start of a witness' testimony) into the hearsay evidence a witness would present:

\begin{abstract}
Thus, assuming the test of necessity is met by the death of persons involved in the events being testified to. when a witness is called upon to give hearsay evidence counsel should give a bricf outline of the nature of the hearsay evidence to be heard. Before the evidence is heard, there should be a preliminary examination of the witness concerning the following: a) Personal information concerning the altributes of the witness relating to his or her ability to recount hearsay evidence of oral history. practices. events, custons or (raditions. b) In a general way, evidence of the sources of the witness, his or her relationship to those sources and the general reputation of the source. c) Any other information that might bear on the issuc of reliahility. ${ }^{25}$
\end{abstract}

There could then be a challenge to the admissibility of a given witness' testimony upon the conclusion of this preliminary inquiry, or there could be arguments on the weight of particular testimony (using this information, which would be part of the record) at the conclusion of the trial. ${ }^{26}$ Justice Vickers thus seeks to establish a process that will enable a testing of the key questions around evidence that falls in the hearsay category, while still enabling the presentation of oral history evidence where it meets the test for such evidence. The natural question is whether this is an appropriate process in light of the larger law on these matters.

This order has already been applied in a later phase of the case. Canada and British Columbia had objected to admissibility of the evidence of certain witnesses and contents of certain affidavits. Justice Vickers applied the criteria he had offered, and he permitted most of the evidence in question to be admitted. Certain legends which Canada alleged did not go to any issue at trial were admissible to help prove the shared identity of an Aboriginal group. ${ }^{27}$ The testimony of Chief Roger William was admissible, even though Chief William was not an elder, because he had been taught traditional stories by respected persons, many of whom were no longer alive, and because he was well-respected amongst his people, clear from his four-time re-election as Chief. ${ }^{28}$ The testimony of witnesses whose testimony could not be taken as reliable or who were simply reporting second-hand what they had read in history books was not admissible for the truth of its contents, and Vickers J. held that there 
had been proper objections on these issues. ${ }^{29}$ Justice Vickers thus seeks to resolve each evidence question with care and reference to standards of evidence. We can now move on to examine the appropriateness of his foundations.

\section{TOWARD A THEORETICAL RECONCILIATION OF EVIDENTIARY Principles and Aboriginal Oral. History}

The legal issues associated with the reconciliation of Canadian sovereignty and preexisting Aboriginal societies and legal orders pose, of course, immense and widely-noted challenges for the Canadian legal system. These challenges call for new ways of thinking, as is well-noted in Lamer C.J.C.'s succinct note on the challenges framed by the existence of Aboriginal rights: "Aboriginal rights cannot, however, be defined on the basis of the philosophical precepts of the liberal enlightenment.... The task of this Court is to define aboriginal rights in a manner which recognizes that aboriginal rights are rights but which does so without losing sight of the fact that they are rights held by aboriginal people because they are aboriginal. ${ }^{30}$ However, the existence of these broader challenges does not necessitate an insurmountable and unconfined philosophical prolegomenon to a theoretical reconciliation of evidentiary principles and Aboriginal oral history, for the law of evidence itself contains tools able to work with many complex areas of substantive law. In this Part, I will argue, first, that there is an inherent, ongoing dialogue between evidentiary principles and particular areas of substantive law. I will argue, second, that the accommodations that evidence law can make in the interests of justice through such a dialogue are substantial but that various areas of substantive law must also make accommodations so as not to disrupt a fair justice system, pointing briefly in the process, cross-systemically, to their more explicit enunciation in other states' evidence law. I will argue, third, that the more theoretical Supreme Court of Canada cases on Aboriginal oral history, namely Delgamuukw and Mitchell, have sought a reconciliation of these values and thereby achieved a powerful theoretical reconciliation of evidentiary principles and Aboriginal oral history, though one that left many practical aspects thus far unaddressed.

First, then, there is an inherent, ongoing dialogue between evidentiary principles and substantive law. The nettlesome nexus of evidence and substance precedes, of course, even the earliest eras of our common law system. If we think back to the most famous judgment of King Solomon, we can recall a substantive judgment, that of threatening to divide a child between the two women each claiming the boy as her son, designed to elicit evidence more

27. Ibid. at paras. 24, 26-28.

4) Van der Peet, supra note 5 at paras. 19-20 [emphasis in original]. Notable amongst the specific challenges noted in Tsilhqot in Nation Application, supra note 6 at para. 20 is that "Aboriginal title is a right in land, communal in its nature. It is a collective right, held by all members of an aboriginal nation." I have written elsewhere on the philosophical issues associated with collective rights and on how we can work toward understanding the place of collective rights in our legal orders: sec e.g. Divight G. Newman, "Collective Interests and Collective Rights" (2004) 49 Am. J. Juris. 127; Diwight G. Newman. "Putting Kymlicka in Perspective: Canadian Diversity and Collective Rights" in Stephen Tiemey. ed., Accommodating Cultural Diversity: Contemporary Issues in Theony and Practice (London: Ashgate, (forthcoming]); Dwight G. Newman, "Community and Collective Rights". D.Phil. thesis, Oxford University Faculty of Law, to be submitted 2005. 
accurately.11 Our recollections from early law school days in which we heard of the procedural obsessiveness of the early common law are not mistaken, ${ }^{32}$ but they ought properly to yield to a richer understanding of the possible substantive accomplishments available through procedural decisions; as Milsom has put it, "even in those [contexts] in which the historian can see the judges as most clearly 'making law', the judges themselves were thinking in procedural rather than in substantive terms." ${ }^{\text {"3 }}$ There is actually a richer encounter between procedural law, including evidentiary principles, and substantive law than often assumed.

Even in a more modern era, it remains the case that evidentiary concerns can appropriately affect the shape of substantive legal norms. To take a vivid example, admittedly yet more removed from our specific problem, the best moral or constitutional justification for prohibitions on sadomasochistic sexual activity is increasingly recognized to be an evidencerelated justification. Judicial decisions on the issue have tended to amount to little more than an unexplained (and sometimes bashful) paternalism, ${ }^{34}$ which has obviously not been able to persuade all decision makers in the context of contestation around the legislative and judicial entrenchment of moral values in liberal societies. A better rationale is that a prohibition on sadomasochistic activity helps resolve some evidentiary problems that would otherwise arise in the situation of a sexual assault or domestic violence perpetrator who claimed that evidence of physical injury to the alleged victim was evidence only of consensual sadomasochistic activity, the prohibition essentially preserving the possibility of physical evidence supporting the testimony of a sexual assault or domestic violence victim. ${ }^{35}$ The needs of evidence law can appropriately support here a particular substantive norm.

That being said, of course, evidence law can also be subject to modification in the interests of substantive justice concerns originating from other areas of the law. Two examples can help make more manifest this facet of the interaction. First, the rules of evidence are adapted to fit with common sense and so as not to make it impossible to advance substantively just claims; a good example of this phenomenon is the adaptation of the rules on burden for causation in medical negligence contexts, such as in the famous Snell v. Farrell case. ${ }^{30}$ Second, the Supreme Court of Canada has been ready to adapt the law of hearsay from a law consisting of categorical exceptions ${ }^{37}$ to the general prohibition on out-of-court statements being admitted for the truth of their contents, replacing the categorical exceptions with a principled approach. This change was apparently initially motivated by hopes of avoiding

"I Kings 3:16-28 describes the wisdom of King Solomon's approach, which led to the real mother offering to give up her claim, thus permitting her identification.

Gerald Postema, "Classical Common Law Jurisprudence (Part 1)" (2002) 2 O.U.C.I.J. I55 at 161

S.F.C. Milsom. Studies in the History of the Common Latl' (London: Hambledon Press. 1985) at 212

Sec e.g. R. v. Brown (1993). [1994] I A.C. 212 (11.L.). Cf R. v. Jobidon. [1991] 2 S.C.R. 714 and $R$ v. Paice, [2005] I S.C.R. 339, 2005 SCC 22 (both dealing with the analogous issue of consensual list fights).

1s For recent legal scholarship that has begun to adopt this rationale, sec e.g. Monica Pa. "Beyond the Pleasure Principle: The Criminalization of Consensual Sadomasochistic Sex" (2001) 11 Tex. J. Women \& L. 51 at 85.88.

4. [1990] 2S.C.R. 311.

1 The traditional exceptions are in J.H. Chadbourn. ed.. Wigmore on Evidence. $3 \mathrm{~d}$ ed., vol. 5 (13ustun Little, Brown, 1974) at \$1427. 
trauma to child witnesses who had suffered abuse, as, in $K$ han ${ }^{38}$ the Court held that hearsay evidence of the out-of-court statements of a child alleging abuse could be admitted provided that this evidence met the principled criteria of necessity and reliability. However, the change was a broader one, replacing in general the old categorical exceptions to the hearsay rule with a principled approach. ${ }^{39}$ The rules on hearsay thus become generally more responsive to the realities of individual contexts, ${ }^{40}$ thus modifying evidentiary principles to pursue substantive justice. This modification can pose challenges; as I have discussed elsewhere, ${ }^{41}$ the Supreme Court of Canada in 1999 and 2001 reached dramatically different conclusions on the admission of hearsay in two sexual assault cases in but slightly different factual circumstances. ${ }^{42}$ An attention to individual circumstances can thus create challenges for the certainty of the law in the pursuit of justice.

There is, then, a sense in which evidentiary principles and substantive law appropriately shape one another. There is an ongoing dialogue between them, with a mutual interaction in their content. The question that logically flows from this realization is whether the appropriate interaction between them is conditioned by further values. A full description of these values, of course, extends beyond the scope of this comment, but we can approximately characterize the operative values. The realization flowing from a careful reading of this interaction is that the interaction is between bodies of law seeking to embody two different, though related values. Substantive areas of the law seek to embody principles of substantive justice; evidence, as a species of procedural law, seeks to embody a sort of procedural justice, a call for a fair justice system. The former claim flows from a generalized interpretation of the objectives of law, on the best interpretation of legal practice. ${ }^{33}$ The latter flows from an understanding of what procedural law could seek to embody, though it finds also support in specific references in Canadian case law, where judges concerned with evidence law have specifically described the operative value in such terms. ${ }^{44}$

These values, apparent in Canadian evidence law, are perhaps even more apparent in other states' evidence law, which due to the common core of evidentiary principles can provide a mirror for our own principles. Other states have also shifted away from the categorical

Supra note 19.

" Early interpretations of Khan as establishing simply a new exception for testimony of children in certain coniexts (e.g. R. v. Jack (1992), 70 C.C.C. (3d) 67 at 113 per O'Sullivan J.A. (Man. C.A.)) were swiflly rejected (in R. v. Smith. [1992] 2 S.C.R. 91S and R. v. B.(K.G.). [1993] I S.C.R. 740), and it has now become apparent that the old exceptions are subject to revision based on the principled analysis $(R, v$. Starr, [2000] 2 S.C.R. 144, 2000 SCC 40 at paras. 155. 191-94, 201, 213 [Starr]). See generally J. Sopinka, S. N. Lederman \& A. W. Bryant, The Law of Evidence in Canada. $2 \mathrm{~d}$ ed (Toronto: Butterworths, 1999) at 189-201.

" Dwight G. Newman, "A Study of the Judgments of the Saskatchewan Court of Appeal, 2000" (2002) 65 Sask. L. Rev. 107 at 123.

: See R. v. F.(W.J.), [1999] 3 S.C.R. 569 (with the Court split between the majority judgment of McLachlin J. (as she then was) accepting necessity and reliability for the use of the hearsay at issuc and Lamer C.J.C.'s questioning of the use of the particular hearsay); and R. v. Parrolt, [2001 ] I S.C.R. 178. 2001 SCC 3 [Parroul] (with the Court closely split between the majority judgment of Binnie J. rejecting the use of hearsay in the case and the minurity judgment of LeBel J. accepting it).

" I am indebted to John Whyte for observations on this point.

"4 Sec e.g. R. v. F.(W.J.). supra note 42 at para. 2 ("the importance to a fair justice system of trial judges" treating hearsay evidence in a prudent fashion" per Lamer C. J.C.); Starr, supra note 39 at para. 199 ("the hearsay rule serves as a cornersione of a fair justice system" per lacobucci J.). 
exceptions approach to hearsay. The United States Supreme Court adopted an approach permitting the admission of hearsay based on necessity and reliability as early as 1960, and the judgment accomplishing the change seems to contain these values. ${ }^{\text {ts }}$ South Africa amended its evidence legislation in 1988 to include a judicial power to admit hearsay based on a guided discretion, to be informed inter alia by "the nature of proceedings," the reasons for the use of hearsay, and other factors which go to whether "such evidence should be admitted in the interests of justice," substantive justice. The English law abolished the prohibition on hearsay in civil proceedings in $1995,{ }^{47}$ but with protections meant to allow a serious questioning of the reliability of any hearsay evidence and a "proper evaluation of its weight," between justice-based needs to introduce hearsay and justice system needs to regulate it. Cross-systemic hearsay law thus provides a mirror for Canadian principles, and it helps further illuminate the values at play in evidence law more generally.

We can actually see a reconciliation of these values of justice and a fair justice system (obviously, not inherently opposed values in the first place) in the Supreme Court of Canada's theorizing on the reconciliation of evidentiary principles such as those governing hearsay and Aboriginal oral history in its recent case law commenting on the issue. The Court has of course long recognized the need, in the interests of substantive justice to Aboriginal peoples, to avoid creating an impossibly, inappropriately high burden of proof. ${ }^{49}$ But this began to be applied more directly to oral history from its 1996 decision in Van der Peet:

In determining whether an aboriginal claimant has produced evidence sufficient to demonsirate that her activity is an aspect of a practice, custom or tradition integral to a distinctive aboriginal culture, a court should appronch the rules of evidence, and interpret the cvidence that exists, with a consciousness of the special nature of aboriginal claims, and of the evidentiary diflicultics in proving a right which originates in times where there were no written records of the practices. customs and traditions engaged in. The courts must not undervalue the evidence presented by aboriginal claimants simply because that evidence does not conform precisely with the evidentiary standards that would be applied in. for example, a private law torts case. ${ }^{90}$

Delgamuukw, endeavouring to flesh out these principles, ${ }^{51}$ drew on both the Van der Peet rationale in terms of substantive justice ${ }^{52}$ and on a need to reconcile common law and Aboriginal perspectives as part of a broader mission of reconciliation. ${ }^{53}$ Although oral histories relaying out-of-court statements for their truth would normally offend the rule

Ohio v. Roberts, 448 U.S. 56 (1960).

See $s .3$ of the Law of Evidence Amendment Act. No. 45 of 1988. Principles have developed around this section, including that its use to permit hearsay in criminal proceedings should be very rare dut to thi liberty interests at stake and that the old calcgorical exceptions should not govern but cant provide somic guidance: Hewan v. Kourre, (1993) 3 S.A. 233 (T.).

See ss. 1, 4.5 of the Civil Eividence Act 1995 (U.K.), 1995, c. 38.

Ibid., s. 4(2)(f).

Sec e.g. R. v. Simon, [1985] 2 S.C.R. 387 at 408 [Simon].

Van der Peet, supra note 5 at para. 68.

Delgamusukw, supra note I at para. 3.

Ibid. at para. 105.

Sec e.g. ibid. at para. 156 
against hearsay, ${ }^{54}$ the Court was able implicitly to draw on its modification of the hearsay rule, discussed above, ${ }^{\text {s5 }}$ to find a "case-by-case" ${ }^{\text {"s6 }}$ place for oral histories:

Notwithstanding the challenges created by the use of oral histories as proof of historical facts, the laws of evidence must be adapted in order that this type of evidence can be accommodated and placed on an equal footing with the types of historical evidence that courts are familiar with, which largely consists of historical documents. ${ }^{57}$

The Court thus rejected the reasoning of the trial judge, ruling that the trial judgment had systemically undervalued oral history. ${ }^{\mathrm{s}}$ Thus, the place of oral histories was meant to be assured not just at the admissibility stage, but at the weight stage as well, in a judgment offering oral history an expansive scope.

The Court, at the same time, has had to remain true to the values of a fair justice system. In Marshall, in the slightly different context of the use of extrinsic evidence in interpreting treaties, Binnie J. poignantly observed: “'Generous' rules of interpretation should not be confused with a vague sense of after-the-fact largesse. The special rules are dictated by the special difficulties of ascertaining what in fact was agreed to."s9 Justice McLachlin (as she then was), referring specifically to this statement, ${ }^{60}$ has more recently in Mitchell endeavoured to make clear the "continued applicability of the rules of evidence" even with adaptations to permit the use of oral history. ${ }^{61}$ More generally, Mitchell amounts to a statement that common sense rules of evidence do apply to Aboriginal oral history, though this common sense must include a consciousness of the special Aboriginal context. ${ }^{62}$ Requirements in other cases of "due weight" or "equal treatment" for evidence of Aboriginal claims do not mean artificial admissibility or weight, but appropriate admissibility and weight based on a fair decision not inattentive to the special nature of Aboriginal oral history. ${ }^{63}$ Justice McLachlin thus essentially reinvokes the general principles applying to hearsay and the principled approach to exceptions:

As noted by ibid. at para. 86 .

Sec text accompanying notes $37-42,45-48$.

Delgamuukw, supra note 1 at para. 87.

Ibid.

Ibid. at para. 98. The lengthy trial judgment of Mctachern C.J.B.C. had examined general difficulties with oral history evidence, referring to the challenges in distinguishing the claimed factual content (at $243,246,247-48$ ), the potential biases of oral history recounted by those involved in preparing a lawsuit (at 248), the potential that anthropologists might be required by their ethical codes to act in favour of the groups they studied (at 248-51), and the specific problems in the case that the oral histories had been subject to serious questioning under cross-examination (at 259), all of which, along with general issues around consistency and lack of detail (at 250-60), had led him to place little weight on the oral histories in the case: Delgamunkw v. British Columbia (1991), 79 D.L.R. (4th) I85 (B.C.S.C.) [Delgamuakw (Trial)]. This reasoning was not accepted in the context of the Supreme Court of Canada's expansive moves in favour of ozal history evidence in Delgamuukw, though we shall later see similar factors returning.

R. v. Marshall, [1999] 3 S.C.R. 456 at para. 14 [Marshall]. The rehearing judgment in the case also referred to the need for "proper historical evidence" for treaty rights: $R$. v. Marshall, [1999] 3 S.C.R. 533 at para. 20.

Mitchell, supra note 4 at para. 39.

Ibid. at para. 29.

See ibid. at paras. 37-38.

Ibid. at para. 39. 
Underlying the diverse rules on the admissibility of evidence are three simple ideas. First, the evidence must be useful in the sense of tending to prove a fact relevant to the issues in the case. Second, the evidence must be reasonably reliable; unreliable evidence may hinder the search for the truth more than help it. Third, even useful and reasonably reliable evidence may be excluded in the discretion of the trial judge if its probative value is overshadowed by its potential for prejudice. ${ }^{64}$

These principles, McLachlin J. notes, can also ground a testing of particular testimony. The particular words she uses are important, for they lead to a further controversy to which we will attend in a moment: "The trial judge need not go so far as to find a special guarantee of reliability. However, inquiries as to the witness's ability to know and testify to orally transmitted aboriginal traditions and history may be appropriare both on the question of admissibility and the weight to be assigned the evidence if admitted."'s5 The reconciliation sought, then, is not one that abandons reference to the principled hearsay test or other evidentiary principles, but one that attends appropriately to the need for and special nature of evidence that arises in the Aboriginal claims context. In other words, there must be a consciousness of the need for substantive justice appropriate in these sorts of cases, but there cannot be an abandonment of the need for a fair justice system that tests claims in a just manner. The Court seeks to reconcile the values it has had to reconcile in other evidentiary contexts and to establish an intellectually and morally coherent law.

Recent lower court decisions have responded to the Supreme Court's complex message. In some cases, oral history types of evidence have been admitted without difficulty, as appropriately addressing the relevant issues while overcoming challenges to them. ${ }^{66}$ In other cases, judges have conducted careful analyses of the Supreme Court's directions. In $R$. $v$. Haines, a provincial court judge dealing with an over-fishing charge met by claims of Aboriginal rights carried out a lengthy analysis of the principles applying to oral history in the Supreme Court's case law and went on to examine carefully the background of different witnesses as to how it fit with the requirements for reliability, eventually accepting their testimony as proof of fishing practices. ${ }^{67}$ In a different sort of fisheries case, a federal court judge carried out a careful analysis of the minimal threshold of reliability for the admissibility of oral history evidence, in an effort to determine whether a different First Nation with intervener status could introduce independent testimony to establish its conflicting claim to Aboriginal fishing rights in the area under question; here, the main testimony at issue was irreconcilably inconsistent with affidavit evidence from the same person and thus inadmissible. ${ }^{68}$ The careful consideration of evidence in various cases goes on routinely and

Ibid. at para. 30.

Ibid. at para. 33 [emphasis added].

E.g. R. v. Morris (2004), 237 D.L.R. (4th) 693, 2004 BCCA 121 (accepting evidence from members as to ancient customs and traditions around hunting): Lac La Ronge Indian Band v. Canada (2001). 206 D.L.R. (4th) 638, 2001 SKCA 109 [I.ac La Ronge] (admitting oral evidence where written evidence was absent, though with some caution about the testimony of witnesses closely involved with the preparation of litigation). Cf. Edgar v. Kitasoo Band Council (2003). 236 F.T.R. 314. 2003 FCT 815 (para. 17 accepting oral history if there had been insufficient documentary evidence, but here tinding the oral history was not needed; taking the Court at its word, oral history would have been unproblematic if it had been needed).

R. v. Haines, [2003] I C.N.L.R. 19$]$ at paras. 100-117 (B.C. Prov. Ct.).

Hwiltsum First Nation v. Canada (Minister of Fisheries and Oceans). [2001] I.C.J. No. I308 (QL). 2001 FCT 936 [Hwilitsum]. 
is perhaps a tonic to the impression one might gather from the highest appellate jurisprudence of continual legal controversy.

However, one important controversy pertinent to the case at issue does arise from a recent case conceming the tax exemption available to the Aboriginal signatories of Treaty 8 . In Benoit $v$. Canada, ${ }^{69}$ the Federal Court of Appeal, with the Supreme Court refusing leave to appeal, ruled that Mitchell established a boundary on oral historical evidence that could not be crossed and that hearsay evidence must be rejected if it did not meet the appropriate reliability test. ${ }^{70}$ On this interpretation, Nadon J.A. also arrived at the interpretation that "[a]t paragraph 33 of her Reasons in Mitchell, supra, McLachlin C.J., stated that $i t$ was necessary' to inquire into a witness' ability to know and to testify with respect to the tradition and history orally transmitted." "Counter to the conclusion in the Tsilhqot 'in Nation Order which had been based on the permissive "may" of that paragraph of Mitchell, ${ }^{2}$ Benoit thus would render an inquiry process into something mandatory, an issue to which we will return in the last section. In any event, the Court in Benoit was ready to apply a tough test to oral history, requiring a consideration of its general problems, ${ }^{73}$ trying to draw the conclusion from Mitchell that "depending on the nature of the oral history at issue, corroboration may well be necessary to render it reliable, ${ }^{174}$ and concluding that the oral history at issue differed from the more formally transmitted history in Delgamuukw, thus rendering it suspect. ${ }^{73}$ This lower court decision thus opens new challenges to oral history, particularly as to how, practically, the reconciliation with evidentiary principles is to take place.

Thus, we see a powerful theoretical reconciliation of evidentiary principles and Aboriginal oral history. But the Supreme Court of Canada's cases left relatively unaddressed how this reconciliation was to work in judicial practice, something which the lower courts began to run up against more seriously. A reluctance to set out a full set of rules on the matter flowed no doubt from a combination of a general restraint from pronouncing too extensively on matters not specifically before the Court, a specific awareness of the need for tlexible contextual consideration in this relatively unknown area before overly rigid rules prescribe fully its evolution, and a specifically stated judicial preference for governmental negotiation of Aboriginal claims. This judicial preference for negotiation on Aboriginal claims, aside from being stated in Canadian law, ${ }^{76}$ has generalizable theoretical rationales ${ }^{77}$ and would be

Benoit v. Canada (2003), 228 D.L.R. (4t11) I. 2003 FCA 236. Leave to appeill refused. [2003] S.C.C.A No. 387 (QL) [Benoir].

"1. $\quad$ bid. at paras. $23,100$.

Ibid. at para. 102 [emphasis added].

Mitchell, supra note 4 at para. 33.

Benoit, supra note 69 at para. 105 . This reasoning is in tension with Lamer C.J.C.'s criticism of the Delgamusw trial judge for undervaluing oral histories based on merely general concerns: Delgamuuhw. supra note 1 at para. 98.

"Benoit, supra note 69 at para. 113 . This was hased on an observation that .Mitchell had considered oral history along with archatlogical and other historical evidence, though the claim of a corroboration requirement does not, in my view, follow

* $\quad$ lid. at para. 109.

Delgamuzkw', supra note I at para. 186 ("Ultimately, it is tlirough negotialed settlements, with good faith and give and take on all sides. reinforced by the judgments of this Court, that we will achieve whal I stated in Van der Peet, siupra, al para. 31, to be a basic purpose of s. 35(1)- the reconciliation of the pre-existence of aboriginal societies with the sovereignty of the Crown'. Let us lace it. we are all here to stay"); R. v. Sparrow. [1990] I S.C.R. 1075 at I I 115 ("|s. 35] provides a solid constitutional base 
in itself reason enough for the Court to offer only some general principles so as to enable negotiation, in the old phrase, "in the shadow of the law." These reasons aside, however, the reality of the practical application of this reconciliation pressing up against real judicial cases could not be forever prolonged, and the lower courts have had to work toward a more thorough understanding of how these rules might work in the judicial process.

\section{TSilhoot'in Nation as Practical. Reconcil.iation}

The issue, we may recall, arose in the Tsilhqot in Nation case when the defendant British Columbia and Canadian governments sought orders establishing a process for oral history evidence. As a result, in a very real context, the British Columbia Supreme Court had to decide on some principles for the application of the theoretical reconciliation to the practical hearing of actual evidence. The Court did so with an awareness of the efforts of other lower courts facing similar challenges, ${ }^{78}$ though without specific citation to their judgments; we need to consider, in particular, how the conclusions in $T$ silhqot in Nation relate to those in Benoit in the last section. ${ }^{79}$ In this section, 1 will argue that the principles expressed in the Tsilhgor 'in Nation order are a reasonable effort toward such a practical reconciliation, that they are more generalizable than the judgment suggests (and here. Benoit has an important point, though it is mistaken in some of its other conclusions), but that some additional principles present in recent American legal discussion on Aboriginal oral history issues might usefully enhance the principled practical framework we can appropriately develop in future Canadian legal discourse.

First, then, we can hold up the key principles inherent in the Tsilhqor 'in Nation order to the lens of the theoretical reconciliation of Part III. The order provides two elements to a process. First, it suggests that lawyers provide a general introduction to the nature of oral evidence in the case. This introduction effectively creates room for the opening of consciousnesses as to the special nature of oral history. It offers scope for lawyers to remind the Court of the need for oral history in line with all of the rationales discussed. It gives lawyers an opportunity to make clear to the Court the nature of oral history evidence in the particular community and why it should be considered as potentially having reliability. This element of the process thus responds to the important need to take careful account of Aboriginal perspectives and to incorporate oral history in the interests of substantive justice.

upon which subsequent negotiations can take place"): (Ne/gamuuhor v: British ("ohumbia (1943). 11)4 D.L.R. (4th) 470 at paras. 618-19,697 (B.C.C.A.) [Delgamuukw (C.A.)] (L.ambert J.A. noting a strong preference for negotiation. and connecting this to the difficulties of basing a fixed right on history and anthropology that experts in those ficlds may later decide was mistaken).

Aside from Lambert J.A. 's rationale in Delgammikw' (C. A.). ibid., we slould note particular challenges: related to the judiciary being involved. Polycentric claims. involving overlapping claims (such as in Huvilisum. supra note 68, where rival First Nation groups claimed fishing rights in the same terrilory). may be difficult to resolve in a judicial context when the court is presented only with what the parlics to the case bring. Certain sorts of religious traditions within Aboriginal communities may be sccret. which can pose issues for a coun dealing with them in litigation. And there is the general diflicully ol access to justice. though rigid policies of governmental negotiation may mol make negoliation a substantially more accessible protess.

ix Tsilhqot in Nation Order, sipra note 6 at para. 16

". See. in particular. note 71 and accompanying text 
Second, the order provides a process for a testing of the admissibility of each piece of oral history evidence, something which emerges as important in the case law. By making the inquiry into the evidence function not through a separate voir dire but through testimony at the start of each witness' appearance, the order makes it possible to challenge particular testimony either at the admissibility stage and/or at the later weight stage. In the law of evidence, the admissibility of hearsay does not depend on its ultimate reliability, ${ }^{80}$ but on a preliminary sort of reliability, and the Tsilhgot 'in Nation order observes this distinction, allowing questioning of reliability that goes to admissibility or to weight. The order thus enables the sort of testing important to a fair justice system and to the continued applicability of evidentiary principles.

Consistently with the evolution of Canadian hearsay law and the international analysis of hearsay issues, Vickers $\mathrm{J}$. adopts a flexible approach, not indicating definitively that hearsay must always be the last option, but posing serious questions against any use of hearsay that does not permit the adversary and the Court the best possible opportunity to test out the evidence. Some flexibility of this sort is, of course, welcome and pragmatic in a civil context, where rights of full answer and defence are not at stake, ${ }^{81}$ and where issues of what might confuse a jury are generally less relevant, ${ }^{82}$ but where getting at the truth retains its overriding importance. The Tsilhgot 'in Nation order incorporates a process that helps to get at the truth, without developing rigid procedural rules that stifle the appropriate use of oral history evidence.

The Tsilhgot 'in Nation order could, of course, be developed further to incorporate some additional tests that could reasonably function within the framework. For example, specific space might appropriately be made for a further question in the reliability phase concerning the relationship of particular witnesses to the preparation of the litigation. Although a role in the litigation should not be an absolute bar to the testimony of an important witness, it cannot be considered irrelevant either, as some courts have recognized ${ }^{33}$ Thus, there may be scope for a further refinement of the process Vickers J. has developed. That being said, we must acknowledge his order as a very good effort at a practical reconciliation of the values at play.

Second, although Justice Vickers describes his order as particular to the case, ${ }^{84}$ there are reasons to take it as more generalizable. Justice McLachlin's language in Mitchell was

Starr, supra note 39 at para. 217.

The right to full answer and defence provides a strong rationale for not permitting hearsay that denies a right of full answer and defence in the criminal law context: e.g. Parrott, supra note 42 at para. 51 (Binnie J.). Note that this distinction between hearsay in criminal and civil law contexts has also been drawn in other states: see notes $46-47$ and accompanying lext.

As lacobucci J. has somewhat boldly put it, "the entire law of evidence is premised on the notion that relevant, probative evidence should on occasion be kept from juries because of their potential inability to assess its weight properly" (Starr, supra note 39 at para. 185).

Lac La Ronge, supra note 66 at para. 37; Delgamuukv (Trial), supra note 58 at 248-51, 271. However, Lamer C.J.C. in Delgamuskw, supra note I at para. 106, sounds some cautions about this, noting that it may prevent the kind of discussion needed to keep the oral history alive; obviously, there is a need for sensitive analysis here. That being said, however, the Saskatchewan Coun of Appeal's more recent decision in Lac La Ronge, supra note 66, is highly persuasive that the factor cannot be ignored.

Tsilhgot in Nation Order, supra note 6 at para. 23. 
permissive: "The trial judge need not go so far as to find a special guarantee of reliability. However, inquiries as to the witness's ability to know and testify to orally transmitted aboriginal traditions and history may be appropriate both on the question of admissibility and the weight to be assigned the evidence if admitted. ${ }^{.85}$ However, a move beyond the literal text of this paragraph to a more structural understanding of the judgment militates for a more mandatory interpretation, as suggested by Benoit. ${ }^{86}$ The Mitchell case itself involves an inquiry into the reliability of oral history evidence, ${ }^{87}$ so its own reasoning processes point to the usefulness of such inquiries. Moreover, the structural point of the Mirchell judgment is that reliability of the evidence must be well-grounded if the admission of oral history is to help and not hinder the search for truth, if the use of oral history evidence is not to constitute an offence of sorts against the workings of a fair justice system. So, we should read up the permissive wording into something requiring inquiries as appropriate to the case before the court. On this conclusion, the applicability of a process like that in Tsilhgor 'in Nation rapidly becomes generalizable, its process being more balanced than the general questioning language of Benoit, and its process being well-justified for the reasons outlined above.

Third, the great merits and generalizability of the Tsilhqot in Nation analysis notwithstanding, we might appropriately supplement its principles with additional principles from elsewhere, whether for purposes of specific legal determinations or whether for more strategic aspects of how lawyers might best advance claims within a framework like Tsilhqot'in Nation. In particular, we can find some helpful principles in some recent American legal discourse on issues of Aboriginal oral history.

In certain self-congratulatory moments, Canadian law might think of its response on Aboriginal oral history as having much to teach the world and little to learn from elsewhere. And, of course, Delgamuukw has been an inspiration to lawyers operating outside Canada as well. ${ }^{88}$ However, the achievement of Delgamuukw in this context ought not to, in the process, insulate us from learning from others. It is sometimes almost forgotten that the Supreme Court of Canada's openness to oral history in Delgamuukw was not an entirely novel attitude, even though previous Canadian cases had already begun the process of opening to oral history evidence. ${ }^{89}$ We can, moreover, also sometimes see a pragmatic use of oral history evidence in even earlier cases elsewhere. ${ }^{90}$

Mitchell, supra note 4 at para 33 [emphasis added]. The French text of the judgment also uses permissive language: "il peut être approprié de s'enquérir."

Benoit, supra note 69 at para. 102 ("[a]t paragraph 33 of her Reasons in Mitchell, supra, McLachlin C.J., stated that if was necessary to inquire into a witness' ability to know and to testify with respect to the tradition and history orally transmitted" [emphasis added]).

"Grand Chief Mitchell's testimony, confirmed by archaoological and historical evidence, was especially useful because he was trained from an carly age in the history of his community": Mischell, supra note 4 at para. 33.

See e.g. "The Creation Story of Peoples," supra note 2 at 53.

Van der Peet, supro note 5 at para. 68; Simon, supra note 49 at 408.

As a methodology, of course, use of oral history has existed long indeed. as is apparent from the seminal work of Jan Vansina, Oral Tradition: A Study in Historical Methodology, trans. by H.M.W. Wright (Chicago: Aldine, 1965). For a helpful discussion of recent use of oral history in the American legal context, see Glen Stohr, "The Repercussions of Orality in Federal Indian Law" (1999) 31 Ariz. St. L.J. 679. 
In particular, we can refer to the 1987 case of Zuni Tribe of New Mexico v. U.S. ${ }^{91}$ This case, although providing no ringing endorsement of oral history, does provide an example of a court using oral history as part of the evidence for Aboriginal title. Leaving unresolved an issue as to whether oral history required corroboration, ${ }^{92}$ the Court found that the ancient ties of the Zuni to the land in question were "manifest in the tribal oral tradition about Zuni origin and migration and in the physical artifacts representing the archaeological history of Zuni culture." ${ }^{93}$ The Court specifically held that there was evidential value in the oral tradition because of the importance attached in the community to accurate transmission of oral history. ${ }^{\text {t4 }}$ This factor is similar to one raised in the Canadian case law, ${ }^{95}$ but we can learn more from academic commentary on the case. Andrew Wiget, an anthropologist involved in the case, has analyzed why oral history testimony was convincing. ${ }^{\circ 0} \mathrm{He}$ concludes that its presentation in a deposition form rather than in a more free-flowing form helped to make it more persuasive to a court. ${ }^{97} \mathrm{He}$ also points to three social scientific factors which the oral history evidence in the case satisfied: "validity," meaning corroboration, which was established through corroboration between different pieces of the oral history testimony; "reliability," or repeatability, tested through the ability of deponents to tell the same story on various occasions; and "consistency." meaning the conformity of testimony with other testimony. ${ }^{98}$ Factors along these lines are, of course, already implicit in the way in which courts consider evidence, but this analysis of the Zuni case can help serve as a reminder of factors that could be legally relevant (or relevant to fact-finding) and thus are strategically relevant to lawyers advocating in such cases. There is room for ongoing interaction between lawyers and social scientists on appropriate methods of truth-seeking in oral history contexts. ${ }^{\text {99 }}$ Some of these factors might help to structure a currently (somewhat inherently) unstructured process of assigning weight to oral history evidence, which might appropriately have a relationship with the Tsilhqor in Nation order insofar as its preliminary inquiry into witnesses is one means of helping to highlight specific issues related to the weight of particular testimony.

$12 \mathrm{Cl}$ Cl. 607 (1987).

lbid. at 607 . n. 1 . This matter seems not to go to rest in Canada either. with the suggestion in Benoif, supra note 69 at para. 113 . Sec my comment. supra nole 74 above.

Zumi Tribe of New Mexico v. U.S, ibid. al 616.

Ibid. it 617, 11. 12.

Cf. Tsilhoof in Nation Order, supro note 6 at paras. 6.9 (Inaking a prelininary finding of such a character to oral history at issut and thus potentially accepting its reliability) and Benoit, supra notc 69 at para. 109 (not finding such a character in particular oral history and thereby distinguishing itself from the application of Delgamukiw', stupra note 1).

Andrew Wiget. "Recovering the Remembered Past: Folklore and Oral History in the Zuni Trust Lands Damages Case" in E. Richard Hart. ed., Zuni and the Courts: A Siruggle for Sovereign Land Rights (lawrence: University Press of Kansas, 1995) 173.

Ibid. al $175-76$.

lbid. at $177-79$.

The discussion that will take place is not necessarily simple. Some sucial sceentists may object even to the aim of "truth-seeking." as they have the perspective that there is met one truth of the inatter to be discovered. Oral history functions in different ways for different users of oral history. For Aboriginal groups themselves. it will have a broader cultural meaning, for social scientists a use as a source of some perspectives on the history or anthropology of a group, and for lawyers a circuinseribed use in the determination of legally recognized facts. Lawyers cannot give up this aim willoul sacrificing the law's claim to determining legal rights and wrongs. The result is that cross-disciplinary discussions are likely to involve continuing strifi. but this fact is no reason to abandon them. but one to maintain them. 
Thus, the Tsilhqot 'in Nation order manages a practical reconciliation consistent with the theoretical reconciliation that serves as our legal background. This practical reconciliation is even more generalizable than Vickers J. might have thought. At the same time, there is room for ongoing dialogue with other sources and learning from others as to appropriate methods of considering oral history in developing this sort of common-law civil procedure.

\section{CONCLUISIONS}

Wisdom is often present in places where our elites are less habituated to looking. The Tsilhgot in Nation order is an example of this phenomenon. Confronting the kinds of practical issues that did not reach the radar screens of the Supreme Court of Canada, Vickers J. has crafted a process that has the potential to serve well the operative values of our legal system.

This comment has argued that there is a broad mission of reconciliation present in the jurisprudence dealing with evidence law and with the interaction of evidence law and Aboriginal oral history. Evidence law and substantive law are in an inherent, ongoing interaction, one seeking reconciliation of the values of substantive justice and a fair justice system. Case law specifically on evidence law and Aboriginal oral history seeks to reconcile these values, as well as common law and Aboriginal perspectives.

The Tsilhqot in Nation order goes far in terms of accomplishing such a reconciliation at a practical level, one concerned with civil justice, and its main process is to be commended. Despite the inclination of Vickers $J$. to describe it as designed simply for the case at hand, the process he has developed is more generalizable. That being said, there is something to learn from other contexts also, something which. of course. Vickers J. never denied. There will be more to be said on these complex issues, but the Tsilhgor 'in Nation order is a wise beginning indeed. 